\title{
Characterization of $\beta 2$-microglobulin expression in different types of breast cancer
}

\author{
Kesheng $\mathrm{Li}^{1 *}$, Huifen Du', Xiaowen Lian', Suisheng Yang ${ }^{2 *}$, Dandan Chai ${ }^{1}$, Chunya Wang ${ }^{1}$, Rong Yang ${ }^{3}$ \\ and Xuezhong Chen ${ }^{4}$
}

\begin{abstract}
Background: Beta-2-microglobulin ( $\beta 2-\mathrm{M}$ ) has been demonstrated as a growth factor and signaling molecule in breast cancer and leukemia. The purpose of the study is to characterize $\beta 2-\mathrm{M}$ expression in molecular subtypes of breast cancer, thereby investigating the mechanism of $\beta 2-\mathrm{M}$ action in breast cancer.

Methods: $\beta 2-\mathrm{M}$ and B-Cell Lymphoma/Leukemia 2 (Bcl-2) transcript expression levels in breast cancer tissue and the corresponding normal tissue were quantified using real-time PCR. The protein expression levels of $\beta 2-M$, estrogen receptor (ER), progesterone receptor (PR), human epidermal growth factor receptor 2 (HER-2), tumor protein 53 (p53) and Ki67 were determined by immunohistochemical (IHC) staining. Following silencing of the $\beta 2-M$ by siRNA, the levels of Bcl-2, ER, PR and HER-2 transcripts and the protein expression levels in human breast cancer cells were measured by real-time PCR and western blotting, respectively.

Results: The expression of $\beta 2-\mathrm{M}$ transcripts demonstrated no significant differences between the four breast cancer molecular subtypes and no significant correlations with age, clinical stage or lymph node metastasis. $\beta 2-\mathrm{M}$ transcript expression demonstrated a positive correlation when compared to $\mathrm{BCl}-2$ transcript expression $(\mathrm{P}<0.05)$. The $\beta 2-\mathrm{M}$ protein expression was significantly higher in breast cancer when compared with benign breast tumors $(P<0.01)$, and have no significant correlation with age, clinical stage or lymph node metastasis. There was a significant difference demonstrated in $\beta 2-\mathrm{M}$ protein expression in the four breast cancer molecular subtypes $(P<0.05)$, and between the $E R^{+}$and $E R^{-}$groups $(P<0.01)$; however, no significant difference was demonstrated between the HER-2 $2^{+}$and HER-2- $2^{-}$groups. $\beta 2-\mathrm{M}$ protein expression had a negative correlation with ER protein expression $(P<0.01)$, a positive correlation with p53 protein expression $(P<0.01)$, and no correlation with Ki67 protein expression. $\beta 2-M$ silencing significantly inhibited Bcl-2 mRNA expression, but did not inhibit ER, PR and HER-2 mRNA expression in MCF-7 cells (ER ${ }^{+}, \mathrm{PR}^{+}$and HER-2- ${ }^{-}$. In addition, BCl-2 and HER-2 mRNA expression were significantly up-regulated in MDA-MB-231 cells ( $\left(E R^{-}, \mathrm{PR}^{-}\right.$and $\left.\mathrm{HER}-2^{-}\right)$, which is consistent with the silencing effect seen at the protein level.
\end{abstract}

Conclusions: $\beta 2-M$ expression demonstrated a significant difference in the four breast cancer molecular subtypes, and may be related to apoptosis regulation in breast cancer.

Keywords: Beta-2-microglobulin, Molecular subtypes, Breast cancer

\footnotetext{
* Correspondence: likesheng63@hotmail.com; 13919820666@126.com

'Department of Medicine Biotechnology, Medicine and Science Research

Institute of Gansu Province, Lanzhou, China

${ }^{2}$ Department of Breast Surgery, Tumor Hospital of Gansu Province, Lanzhou,

China

Full list of author information is available at the end of the article
}

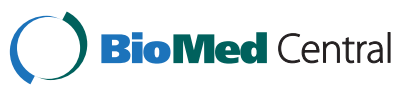

(c) 2014 Li et al.; licensee BioMed Central Ltd. This is an Open Access article distributed under the terms of the Creative Commons Attribution License (http://creativecommons.org/licenses/by/4.0), which permits unrestricted use, distribution, and reproduction in any medium, provided the original work is properly credited. The Creative Commons Public Domain Dedication waiver (http://creativecommons.org/publicdomain/zero/1.0/) applies to the data made available in this article, unless otherwise stated. 


\section{Background}

$\beta 2-\mathrm{M}$ is a low molecular weight protein and is part of the HLA antigen molecule, representing the invariant light chain $[1,2]$. It exists in the membrane of almost all nucleated cells, and is detectable in all body fluids as a shedding product of the cell membrane [3]. In renal disease that presents with the damage of the tubuli renales and increased glomerular filtration rates, quantities of $\beta 2-\mathrm{M}$ in urine are increased. If the rate of glomerular filtration is reduced, the level of serum $\beta 2-\mathrm{M}$ is increased [4]. Therefore, serum and urine concentrations of $\beta 2-\mathrm{M}$ are used to monitor glomerular and tubular nephropathies [5]. The levels of serum and urine $\beta 2-\mathrm{M}$ are also found to be increased in patients with some tumors, including solid tumors and leukemia [6-9]. Thus, the levels of serum $\beta 2-\mathrm{M}$ have become one of the most important prognostic factors and predictors of survival in patients with some tumors [7-9]. Studies have reported that $\beta 2-\mathrm{M}$ is a growth factor and signaling molecule in cancer cells [10-12] and is also a pleiotropic signaling molecule that regulates p21-activated kinases (PAK), androgen receptor, vascular endothelial growth factor (VEGF), fatty acid synthase [12], lipid-raft-mediated growth and survival signaling pathways [13]. The role of $\beta 2-\mathrm{M}$ has been demonstrated in several solid cancers and leukemia; however, the mechanism of $\beta 2-\mathrm{M}$ action is poorly understood.

Although increased $\beta 2-\mathrm{M}$ serum levels in patients with breast cancer have been previously reported $[6,9,12]$, the clinical value of $\beta 2-\mathrm{M}$ as a prognostic factor and predictor of survival, and its mechanism in patients with breast cancer, need further study, since breast cancer has different molecular subtypes [14] and patients with the same clinical stages and pathological types of breast cancer, treated with same scheme, have different therapeutic and prognostic effects. The aim of this study is to characterize $\beta 2-\mathrm{M}$ expression in the different breast cancer molecular subtypes, thereby investigating whether $\beta 2-\mathrm{M}$ is involved with apoptosis regulation in breast cancer. The results of this study will be useful in confirming $\beta 2-\mathrm{M}$-mediated signaling as a new target for breast cancer therapy.

\section{Methods}

\section{Tissue samples}

The tissue samples in this study were collected from 330 patients with breast cancer and 123 patients with benign breast tumors, identified by clinical and histopathological evidence, who underwent surgery at Tumor Hospital of Gansu province. The 164 breast cancer and 123 benign breast tumor tissue samples were from formalin-fixed, paraffin-embedded (FFPE) tissue specimens obtained from the pathology department during surgery performed between 2011 and 2012. The other 166 breast cancer and adjacent normal fresh tissue samples were obtained from surgical specimens resected from patients without previous chemotherapy and radiotherapy during operations performed or examinations by centesis between 2010 and 2013. The fresh tissue samples were frozen at $-80^{\circ} \mathrm{C}$ for preparation of total RNA extraction. The clinicopathological information, including age, node status and tumornode-metastasis (TNM), was obtained from each patient's clinical and pathologic reports. The patient characterizations are listed in Table 1. The Medical Ethics Committee of Medicine and Science Research Institute of Gansu Province approved the study protocol (Reference number: A201301310001) and all patients gave consent for participating in the study and publishing the study results.

\section{Total RNA extraction and real-time PCR}

Total RNA was extracted from the tumor tissues and the adjacent normal tissues using Trizol reagent (Shenggong Biotechnology, Shanghai, China) according to the manufacturer's instructions. The cDNA was synthesized by reverse transcription using the RNA as a template and reverse transcriptase (Shenggong Biotechnology), according to the manufacturer's recommendations. The SYBR premix Ex TaqTM (TaKaRa Biotechnology, Dalian, China) was used for the real-time PCR. Briefly, the $20 \mu \mathrm{l}$ reaction contained $10 \mu \mathrm{l}$ of SYBR premix Ex TaqTM, $1 \mu \mathrm{l}$ of DNA template, $0.4 \mu \mathrm{l}$ of each primer and $8.2 \mu \mathrm{l} \mathrm{dH}_{2} \mathrm{O}$. The PCR cycling conditions included the following steps: $37^{\circ} \mathrm{C}$ for $5 \mathrm{~min}$, $95^{\circ} \mathrm{C}$ for $30 \mathrm{~s}$, and 40 cycles of $95^{\circ} \mathrm{C}$ for $5 \mathrm{~s}$ to $60^{\circ} \mathrm{C}$ for $30 \mathrm{~s}$. $\beta$-actin mRNA was used as the internal control and the reaction mix without template DNA was used as the negative control. All of the samples were measured 3 times independently, and the resulting fluorescence curves represent the number of DNA copies expressed. The primers are listed in Table 2.

\section{IHC staining}

Expression of $\beta 2-\mathrm{M}, \mathrm{ER}, \mathrm{PR}, \mathrm{HER}-2$, p53 and Ki67 in tumor tissues were detected by IHC staining. Sections

Table 1 Patient characterization

\begin{tabular}{lccc}
\hline Variable & $\begin{array}{c}\text { IHC } \\
\text { staining }\end{array}$ & $\begin{array}{c}\text { Real-time PCR } \\
\text { and IHC }\end{array}$ & Total \\
\hline Case no. & 164 & 166 & 330 \\
\hline Age (years) & 126 & 143 & 269 \\
$<59$ & 37 & 21 & 58 \\
$\geq 60$ & & & \\
\hline Stage & 55 & 57 & 112 \\
I+ II & 29 & 40 & 69 \\
III + IV & & & \\
\hline Lymph node metastasis & 59 & 34 & 93 \\
Present & 63 & 53 & 116 \\
Absent & 123 & 0 & 123 \\
\hline Benign breast tumors & &
\end{tabular}


Table 2 Primers used in the real-time PCR

\begin{tabular}{lll}
\hline Gene & Forward primer & Reverse primer \\
\hline $\boldsymbol{\beta}$-actin & 5'-TGGCACCCAGCA $^{\prime}$ & 5'-CTAAGTCATAGT $^{\prime}$ \\
& CAATGAA-3' & CCGCCTAGAAGCA-3' \\
\hline $\boldsymbol{\beta 2 - \boldsymbol { M }}$ & 5'-CGGGCATTCCTG $^{\prime}$ & 5'-GGATGGATGAAA $^{\prime}$ \\
& AAGCTGA-3' & CCCAGACACATAG-3' \\
\hline $\boldsymbol{B c \boldsymbol { c } - \mathbf { 2 }}$ & 5'-TGTATGAACTGA $^{\prime}$ & 5'-CACCTGGCAGCG $^{\prime}$ \\
& GCAATGTGCAAGA-3' & TAGGGTAA-3' \\
\hline
\end{tabular}

from the surgical specimens fixed in $10 \%$ formalin and embedded in paraffin were used for IHC staining by the standard method. Briefly, the paraffin-embedded tissues were cut to a 3-mm thickness, de-paraffinized with xylene and rehydrated through graded ethanol washes. The sections were autoclaved in $10 \mathrm{mM}$ citrate buffer ( $\mathrm{pH}$ 6.0) at $120^{\circ} \mathrm{C}$ for $5 \mathrm{~min}$ for antigen retrieval, cooled to $26^{\circ} \mathrm{C}$, treated with $3 \% \mathrm{H}_{2} \mathrm{O}_{2}$ for $5-10$ min to block endogenous peroxidase activity, and then washed with phosphatebuffered saline (PBS, pH 7.3) for 3 min 3 times. After being blocked with $10 \%$ normal calf serum in PBS for 10-15 min, the sections were incubated at $37^{\circ} \mathrm{C}$ for $2-3 \mathrm{~h}$ with anti- $\beta 2-\mathrm{M}$ (developed by Department of Medicine Biotechnology, Medicine and Science Institute of Gansu Province, Lanzhou, China) at a 1:1000 dilution, then washed with PBS. Next, the sections were incubated with biotinylated secondary antibody (ZYMED, South San Francisco, CA, USA) for $10-15 \mathrm{~min}$ at $37^{\circ} \mathrm{C}$, and then washed with PBS. Horseradish peroxidase polymer conjugate (SP-9000 Histostain TM-plus Kit, ZYMED) was then applied to the sections at $37^{\circ} \mathrm{C}$ for $10-15 \mathrm{~min}$ followed by PBS washes. Finally, the sections were incubated with 33'-Diaminobenzidine (DBA) for 5-10 min. The nuclei were lightly counterstained with hematoxylin. A negative control was run simultaneously by omitting the primary antibody. The stained slides were independently assessed by two pathologists, and any differences in decision outcomes were resolved by consensus. To evaluate the expression of $\beta 2-M$, the tissue sections were examined under a microscope at a magnification of $200 \times$. The results of the tissue sections staining were estimated according to the following: positive, cytoplasm staining or both cytoplasm and cytomembrane staining (mainly cytoplasm staining); negative, no cytomembrane staining. The intensity of staining was classified according to the following scale: negative, 0 ; weak, 1 ; moderate, 2 ; and strong, 3 . Staining was semiquantitatively scored according to proportion of stained cells by the following scale: 0 , no cells stained; $1,<10 \% ; 2$, $10-50 \%$; and $3,>50 \%$ of cells stained. The staining intensity scores and proportion of stained cells were added; the cutoff value for positive expression of $\beta 2-\mathrm{M}$ was defined as moderate staining with $>10 \%$ of cells stained.

The ER, PR, HER-2, p53 and Ki67 (Beijing Zhongshan Jinqiao, Beijing, China) staining procedure was same as that of $\beta 2-\mathrm{M}$ described above. The results of tissue sections stained for ER, PR, p53 and Ki67 were determined according to the following: positive, nucleus staining or both nucleus and cytoplasm staining (mainly nucleus staining); negative, only cytoplasm staining. The cut-off value for positive expression was the same as that of $\beta 2-\mathrm{M}$. The results of tissue sections stained for HER-2 were scored by the ASCO/CAP system: positive, cytomembrane staining; negative, no cytomembrane staining. The cut-off value for positive expression of HER-2 was defined as having more than $10 \%$ of the cells stained.

\section{Silencing of the $\beta 2-M$ gene by siRNA in breast cancer cells} Three siRNAs targeting different regions of $\beta 2-\mathrm{M}$ mRNA [GenBank: NM014002] were designed and purchased from GenePharma (Suzhou, China). Scrambled siRNA (GenePharma) that does not target any gene was used as the negative siRNA control. All siRNAs are detailed in Table 3. Breast cancer cells (MCF-7 and MDA-MB-231, purchased from the Shanghai Cell Bank of Chinese Academy of Sciences, Shanghai, China) were transfected with the siRNAs using Lipofectamine-2000 according to the manufacturer's instructions. Briefly, cells were seeded in a 6-well-plate at a density of $1 \times 10^{5}$ cells/well with antibiotic-free medium $12 \mathrm{~h}$ before transfection. Two microliters of each siRNA $(40 \mu \mathrm{M})$ were mixed with $3 \mu \mathrm{l}$ Lipofectamine-2000 in $50 \mu \mathrm{l}$ serum-free RPMI-1640 medium and were allowed to incubate at room temperature for $25 \mathrm{~min}$ to form a complex. After washing cells with PBS, the $50 \mu$ l transfection mixtures were added to each well with $1950 \mu \mathrm{l}$ RPMI-1640 medium containing 10\% FBS at a final concentration of $40 \mathrm{nM}$ siRNA. Forty-eight hours after transfection, the cells were collected for real-time RT-PCR and western blotting.

\section{Western blotting}

The cultured cells were washed twice with ice-cold PBS and lysed on ice in lysis buffer containing protease and phosphatase inhibitor cocktails. Following a 5-min incubation, the cell lysate was collected by centrifugation at $4^{\circ} \mathrm{C}$ for $10 \mathrm{~min}$ at $12,000 \mathrm{rpm}$. Twenty micrograms of

Table $3 \boldsymbol{\beta} 2-\mathrm{M}$ siRNAs used in this study

\begin{tabular}{ll}
\hline siRNAs & Sequences \\
\hline Negative control (NC) & 5'-UUCUCCGAACGUGUCACGUTT \\
\hline siR-1 (si1) & 5'-CUCCAAGGCUUGCACAGUGCA-5' \\
\hline siR-2 (si2) & TTGAGGUUUCUAAGUCCAAAU-5' \\
\hline siR-3 (si3) & 5'-CCGACAUUGAAGUUGACUUTT \\
& TTGGCUGUAACUUCAACUGAA-5' \\
\hline
\end{tabular}


total protein was separated by SDS-PAGE. The protein was transferred to a nitrocellulose membrane, blocked and then probed with appropriate antibodies. The protein was visualized using horseradish peroxidase-conjugated secondary antibodies and the FluorChem FC2 imaging system. Anti- $\beta 2-\mathrm{M}$ antibody (self-government), anti- $\beta$-actin antibody (Rockland, Gilbertsville, PA, USA), anti-Bcl-2 antibody, anti-HER-2 antibody, anti-ER antibody, anti-PR antibody and horseradish peroxidase-conjugated secondary antibody (Invitrogen, Carlsbad, CA, USA) were used for western blotting.

\section{Statistical analysis}

The data were analyzed using the Statistical Package for Sciences software (IBM-SPSS version 22). The statistical significance of intergroup differences was evaluated using a $\chi^{2}$ test. $\mathrm{P}<0.05$ was considered statistically significant.

\section{Results}

Expression of $\beta 2-\mathrm{M}$ transcripts in breast cancer tissues The expression of $\beta 2-\mathrm{M}$ transcripts was detected by realtime PCR in all 166 breast cancer specimens and their paired normal tissues. The specimens were divided into three groups according to the ratio of the $\beta 2-\mathrm{M}$ transcript levels in the tumor tissue $(\mathrm{T})$ to that in the normal tissue $(\mathrm{N})$ : up-regulation $(\mathrm{T} / \mathrm{N}>2)$, down-regulation $(\mathrm{T} / \mathrm{N}<0.5)$ and no change in expression $(2>\mathrm{T} / \mathrm{N}>0.5)$. The results are shown in Table 4 and demonstrate the following: $15.66 \%(26 / 166)$ up-regulation, $20.48 \%$ (34/166) downregulation and $63.86 \%(106 / 166)$ no change in expression of $\beta 2-\mathrm{M}$ transcripts was observed in the breast cancer specimens. In addition, no significant correlations were found between $\beta 2-\mathrm{M}$ transcript expression level and age, clinical stage or lymph node metastasis; $18.67 \%$ (31/166) up-regulation, 28.92\% (48/166) down-regulation and $52.41 \%$ (87/166) no change in expression of Bcl-2 transcripts were observed in the breast cancer specimens, and no significant correlations were found between $\mathrm{Bcl}-2$ transcript expression level and age, clinical stage or lymph node metastasis.

\section{Expression of $\beta 2-\mathrm{M}$ transcripts in different breast cancer} molecular subtypes

The expression levels of the $\beta 2-\mathrm{M}$ transcripts in different breast cancer molecular subtypes are shown in Table 4 .

Table 4 Expression of $\beta 2-\mathrm{M}$ transcript and clinicopathological and molecular type parameters in breast cancer specimens

\begin{tabular}{|c|c|c|c|c|c|c|c|c|}
\hline \multirow{3}{*}{ Variable } & \multicolumn{3}{|c|}{$\beta 2-M$} & \multirow{3}{*}{ P-value } & \multicolumn{3}{|c|}{$\mathrm{Bcl}-2$} & \multirow{3}{*}{ P-value } \\
\hline & $\mathrm{T} / \mathrm{N}$ & $\mathrm{T} / \mathrm{N}$ & $\mathrm{T} / \mathrm{N}$ & & $\mathrm{T} / \mathrm{N}$ & $\mathrm{T} / \mathrm{N}$ & $\mathrm{T} / \mathrm{N}$ & \\
\hline & $>2$ & $2-0.5$ & $<0.5$ & & $>2$ & $2-0.5$ & $<0.5$ & \\
\hline Case no. & 26 & 106 & 34 & & 31 & 87 & 48 & \\
\hline \multicolumn{9}{|l|}{ Stage } \\
\hline I-II & 11 & 35 & 11 & 0.67 & 8 & 37 & 12 & 0.483 \\
\hline III-IV & 5 & 27 & 8 & & 11 & 19 & 10 & \\
\hline \multicolumn{9}{|l|}{ Age (years) } \\
\hline$<40$ & 3 & 15 & 4 & 0.739 & 4 & 13 & 5 & 0.907 \\
\hline $40-60$ & 21 & 74 & 26 & & 24 & 61 & 36 & \\
\hline$>60$ & 2 & 16 & 3 & & 3 & 11 & 7 & \\
\hline \multicolumn{9}{|l|}{ Lymph node metastasis } \\
\hline Present & 3 & 22 & 9 & 0.316 & 5 & 17 & 12 & 0.981 \\
\hline Absent & 10 & 34 & 9 & & 7 & 27 & 19 & \\
\hline \multicolumn{9}{|l|}{ Molecular subtype } \\
\hline Luminal A & 4 & 33 & 12 & 0.928 & 12 & 28 & 9 & 0.282 \\
\hline Luminal B & 8 & 30 & 11 & & 7 & 23 & 19 & \\
\hline Overexpression of HER-2 & 5 & 19 & 6 & & 6 & 15 & 9 & \\
\hline Basal-like & 2 & 8 & 3 & & 3 & 4 & 6 & \\
\hline$\overline{\mathrm{ER}^{+}}$ & 12 & 63 & 23 & 0.731 & 19 & 51 & 28 & 0.840 \\
\hline $\mathrm{ER}^{-}$ & 8 & 29 & 10 & & 10 & 22 & 15 & \\
\hline HER-2 $^{+}$ & 14 & 50 & 18 & 0.426 & 14 & 40 & 28 & 0.336 \\
\hline HER-2 $^{-}$ & 6 & 42 & 15 & & 15 & 33 & 15 & \\
\hline
\end{tabular}


The expression levels of the $\beta 2-\mathrm{M}$ transcripts, including up-regulation, down-regulation and no change, demonstrated that there was no significant difference in the four breast cancer molecular subtypes $(\mathrm{P}=0.928)$. No significant difference was observed in $\beta 2-\mathrm{M}$ transcript expression levels between the $\mathrm{ER}^{+}$and $\mathrm{ER}^{-}$breast cancer groups $(\mathrm{P}=0.731)$ and the HER-2 ${ }^{+}$and HER-2 breast cancer groups $(P=0.426)$. There was no significant difference in the expression levels of Bcl-2 transcripts in the four breast cancer molecular subtypes, including up-regulation, down-regulation and no change $(\mathrm{P}=0.282)$. In addition, no significant difference was observed in Bcl-2 transcript expression between the $\mathrm{ER}^{+}$and $\mathrm{ER}^{-}$breast cancer groups $(\mathrm{P}=0.840)$ and HER- $2^{+}$and HER-2 $2^{-}$breast cancer groups $(\mathrm{P}=0.336)$ (Table 4).

\section{Association of $\beta 2-\mathrm{M}$ transcript expression with $\mathrm{Bcl}-2$ transcript expression}

The association of $\beta 2-\mathrm{M}$ transcript expression with $\mathrm{Bcl}-2$ transcript expression is shown in Table 5. The $\beta 2-\mathrm{M}$ transcript expression levels have a positive correlation with $\mathrm{Bcl}-2$ transcript expression levels $(\mathrm{P}=0.011)$.

\section{Expression of $\beta 2-\mathrm{M}$ protein in the breast cancer tissues}

The paraffin-embedded sections from the 164 patients' specimens with breast cancer and the 123 patients with benign breast tumors were immunohistochemically stained using $32-\mathrm{M}$, ER, PR, HER-2, p53 and Ki67 antibodies (Figure 1). The results demonstrate that $67.68 \%(111 / 164)$ of sections from breast cancer patients were positively stained by the $\beta 2-\mathrm{M}$ antibody, which is significantly higher than the $34.14 \%(42 / 123)$ positive staining from patients with benign breast tumors $(\mathrm{P}<0.01)$. No significant correlations were found between $\beta 2-\mathrm{M}$ protein expression and age, clinical stage or lymph node metastasis. In addition, $37.03 \%$ p53 and $88.40 \%$ Ki67 positive staining were found in the breast cancer patient sections, and no significant correlations were found between p53 protein expression and age, clinical stage or lymph node metastasis. The expression of the Ki67 protein had a significant correlation with lymph node metastasis $(\mathrm{P}<0.01)$, but no significant correlation with age or clinical stage (Table 6).

\section{Expression of $\beta 2-\mathrm{M}$ protein in different breast cancer molecular subtypes}

The $\beta 2-\mathrm{M}$ protein expression levels in different breast cancer molecular subtypes are shown in Table 6. The expression levels of $\beta 2-\mathrm{M}$ protein demonstrate significant differences in the four breast cancer molecular subtypes $(\mathrm{P}=0.034)$; the rate of positive staining was $56.25 \%$ (Luminal A), 53.33\% (Luminal B), 84.61\% (Overexpression of HER-2) and $73.68 \%$ (Basal-like). Significant differences were also observed in the $\beta 2-\mathrm{M}$ protein expression levels between the $\mathrm{ER}^{+}$and $\mathrm{ER}^{-}$breast cancer groups $(\mathrm{P}<0.01)$; $58.09 \%\left(\mathrm{ER}^{+}\right)$and $81.39 \%\left(\mathrm{ER}^{-}\right)$positive staining were observed in the breast cancer specimen sections. There was no significant difference in the $\beta 2-\mathrm{M}$ protein expression levels between HER-2 $2^{+}$and HER-2 $2^{-}$breast cancer groups $(\mathrm{P}=0.180)$. Both $\mathrm{p} 53$ and Ki67 proteins demonstrated significant differences in expression between the four molecular subtypes $(\mathrm{P}<0.01)$, between the $\mathrm{ER}^{+}$and $\mathrm{ER}^{-}$ groups $(\mathrm{P}<0.01)$, and between HER- $2^{+}$and HER-2 ${ }^{-}$breast cancer groups $(\mathrm{P}<0.01)$.

\section{Association of $\beta 2-M$ protein expression with ER, p53 and Ki67 protein expression}

The association of $\beta 2-\mathrm{M}$ protein expression level with ER, p53 and Ki67 protein expression levels is shown in Table 7. The level of $\beta 2-\mathrm{M}$ protein expression has a negative correlation with ER protein expression $(\mathrm{P}<0.01)$, a positive correlation with $\mathrm{p} 53$ protein expression $(\mathrm{P}<0.01)$ and no correlation with $\mathrm{Ki67}$ protein expression $(\mathrm{P}=0.6)$.

\section{Silencing of $\beta 2-M$ gene by pre-designed siRNAs}

Silencing effects of the pre-designed $\beta 2-\mathrm{M}$ siRNAs were examined in MCF-7 and MDA-MB-231 cells, and a scrambled siRNA was used as the negative control. All three siRNAs showed a significant silencing effect $(\mathrm{P}<$ 0.01 ) and knocked down 80 to $98 \%$ of the $\beta 2-\mathrm{M}$ mRNA in comparison with the scrambled siRNA (Figure 2). Among the $\beta 2-\mathrm{M}$ siRNAs tested, only the siR-3 siRNA showed a significant effect on downstream genes and therefore this siRNA was selected for silencing of the $\beta 2-M$ gene. The mRNA transcript and protein expression levels of $\beta 2-\mathrm{M}, \mathrm{ER}, \mathrm{PR}, \mathrm{HER}-2$ and Bcl-2 were detected by real-time PCR and western blotting after $\beta 2-M$ silencing in MCF-7 and MDA-MB-231 cells. As shown

Table 5 Association of $\beta 2-\mathrm{M}$ transcript expression with $\mathrm{Bcl}-2$ transcript expression

\begin{tabular}{|c|c|c|c|c|c|}
\hline \multirow{2}{*}{$\begin{array}{l}\beta 2-\mathrm{M} \text { transcript } \\
\text { expression }\end{array}$} & \multicolumn{4}{|c|}{ Bcl-2 transcript expression } & \multirow{2}{*}{ P-value } \\
\hline & Up-regulation & No difference & Down-regulation & Total no. & \\
\hline Up-regulation & 20 & 14 & 6 & 40 & 0.011 \\
\hline No difference & 31 & 68 & 21 & 120 & \\
\hline Down-regulation & 8 & 12 & 10 & 30 & \\
\hline Total no. & 59 & 94 & 37 & 190 & \\
\hline
\end{tabular}



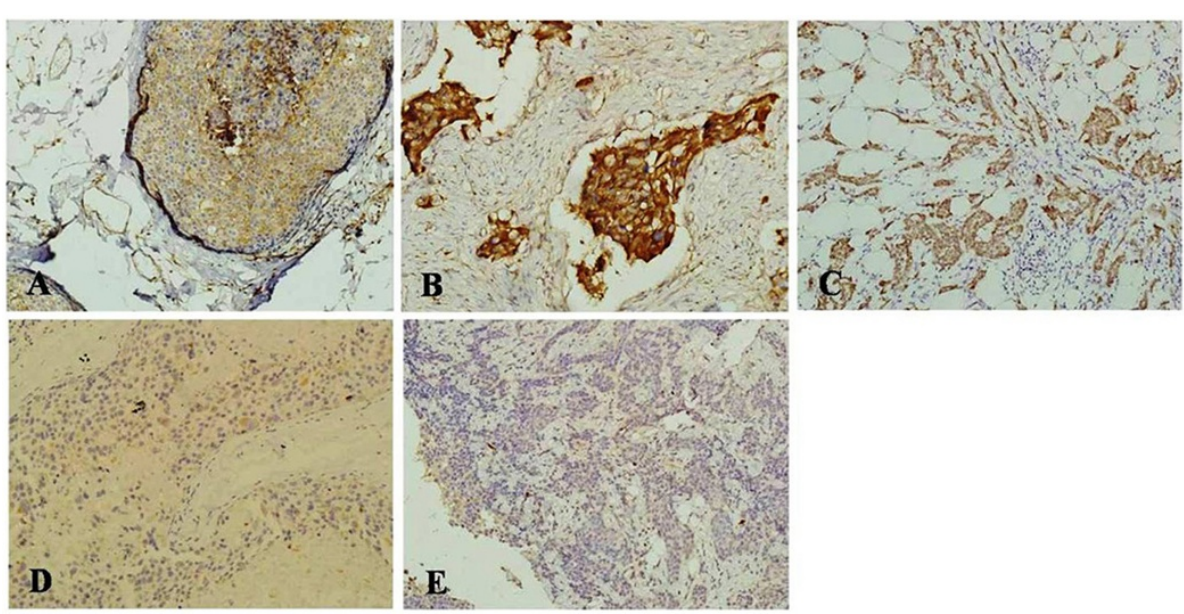

Figure 1 B2-M IHC staining in breast cancer tissue. A) Strong cytomembrane staining; B) Strong cytoplasm staining; C) Moderate cytoplasm staining; D) Weak cytoplasm staining; E) Negative staining. The tissue sections were examined under a microscope at a magnification of 200X.

in Figure 2, siR-3 significantly inhibited Bcl-2 mRNA expression, but did not inhibit the levels of ER, PR, and HER-2 mRNA expression in MCF-7 cells, which is consistent with the silencing effect at the protein level. The Bcl-2 and HER-2 mRNAs were significantly up-regulated by siR-3 silencing in MDA-MB-231 cells, which is also consistent with the silencing effect at the protein level (Figure 2).

\section{Discussion}

Overexpression of $\beta 2-\mathrm{M}$ has been observed in patients with breast cancer $[6,9]$, and studies have shown that

Table 6 Expression of $\beta 2-M$ protein in different breast cancer molecular types

\begin{tabular}{|c|c|c|c|c|c|c|}
\hline \multirow[b]{2}{*}{ Variable } & \multicolumn{2}{|c|}{$\beta 2-M$} & \multicolumn{2}{|c|}{ p53 } & \multicolumn{2}{|c|}{ Ki67 } \\
\hline & $\begin{array}{c}\text { Positive staining } \\
\text { (\%) }\end{array}$ & P-value & $\begin{array}{l}\text { Positive staining } \\
\text { (\%) }\end{array}$ & P-value & $\begin{array}{l}\text { Positive staining } \\
\text { (\%) }\end{array}$ & P-value \\
\hline Breast cancer & $67.68(111 / 164)$ & $<0.01$ & & & & \\
\hline Benign breast tumor & $34.14(42 / 123)$ & & & & & \\
\hline \multicolumn{7}{|l|}{ Age (years) } \\
\hline$<59$ & $65.87(83 / 126)$ & 0.617 & $38.83(40 / 103)$ & 0.506 & $90.56(96 / 106)$ & 0.130 \\
\hline$>60$ & $70.27(26 / 37)$ & & $32.15(10 / 31)$ & & $80.64(25 / 31)$ & \\
\hline \multicolumn{7}{|l|}{ Stage } \\
\hline $1+\|$ & $61.81(34 / 55)$ & 0.515 & $25.53(12 / 47)$ & 0.227 & $82.97(39 / 47)$ & 0.136 \\
\hline III + IV & $68.96(20 / 29)$ & & $34.78(8 / 23)$ & & $95.65(22 / 23)$ & \\
\hline \multicolumn{7}{|l|}{ Lymph node metastasis } \\
\hline Present & $67.79(40 / 59)$ & 0.956 & $40.00(18 / 45)$ & 0.279 & $97.82(45 / 46)$ & $<0.01$ \\
\hline Absent & $68.25(43 / 63)$ & & $29.62(16 / 54)$ & & $79.62(43 / 54)$ & \\
\hline \multicolumn{7}{|l|}{ Molecular subtype } \\
\hline Luminal A & $56.25(36 / 64)$ & 0.034 & $25.00(16 / 64)$ & $<0.01$ & $77.41(48 / 62)$ & $<0.01$ \\
\hline Luminal B & $53.33(16 / 30)$ & & $32.00(8 / 25)$ & & $96.15(25 / 26)$ & \\
\hline Overexpression of HER-2 & $84.61(22 / 26)$ & & $70.83(17 / 24)$ & & $100.00(26 / 26)$ & \\
\hline Basal-like & $73.68(14 / 19)$ & & $38.88(7 / 18)$ & & $94.44(17 / 18)$ & \\
\hline $\mathrm{ER}^{+}$ & $58.06(54 / 93)$ & $<0.01$ & $27.05(23 / 85)$ & $<0.01$ & $82.75(72 / 87)$ & $<0.01$ \\
\hline $\mathrm{ER}^{-}$ & $81.39(35 / 43)$ & & $56.09(23 / 41)$ & & $100.00(43 / 43)$ & \\
\hline HER-2 $^{+}$ & $72.41(42 / 58)$ & 0.180 & $50.98(26 / 51)$ & $<0.01$ & $98.11(52 / 53)$ & $<0.01$ \\
\hline HER-2- & $61.62(53 / 86)$ & & $28.04(23 / 82)$ & & $83.13(69 / 83)$ & \\
\hline
\end{tabular}


Table 7 Association of $\boldsymbol{\beta} 2-\mathrm{M}$ protein expression with ER, p53 and Ki67 protein expression

\begin{tabular}{lcccc}
\hline \multirow{2}{*}{ Variable } & \multicolumn{3}{c}{$\boldsymbol{\beta 2 - M}$ protein expression } & \multirow{2}{*}{ P-value } \\
\cline { 2 - 4 } & Positive (+) & Negative (-) & Total no. & \\
\hline Case no. & 85 & 56 & 141 & $<0.01$ \\
ER $^{+}$ & 46 & 47 & 93 & \\
ER $^{-}$ & 39 & 9 & 48 & \\
\hline Case no. & 84 & 52 & 136 & $<0.01$ \\
p53 $^{+}$ & 36 & 13 & 49 & \\
p53 $^{-}$ & 48 & 39 & 87 & \\
\hline Case no. & 81 & 52 & 133 & 0.60 \\
Ki $67^{+}$ & 73 & 46 & 119 & \\
Ki 67 & 8 & 6 & 14 & \\
\hline
\end{tabular}

$\beta 2-\mathrm{M}$ supports breast cancer bone metastasis [15]. In this study, our results show that: (1) the expression of $\beta 2-\mathrm{M}$ transcripts only demonstrate a $15.66 \%$ up-regulation in the breast cancer specimens, no significant difference in the four breast cancer molecular subtypes, and no significant correlations with age, clinical stage or lymph node metastasis. $\beta 2-\mathrm{M}$ transcript expression has a positive correlation with Bcl-2 transcript expression. (2) Overexpression of the $\beta 2-\mathrm{M}$ protein was significantly higher in breast cancer tissues compared to that in benign breast tumors, and has no significant correlation with age, clinical stage or lymph node metastasis in breast cancer. Expression levels of the $32-\mathrm{M}$ protein are significantly different in the four breast cancer molecular subtypes, significant differences were demonstrated between the $\mathrm{ER}^{+}$and $\mathrm{ER}^{-}$breast cancer groups, but not between the HER-2 ${ }^{+}$and HER-2 ${ }^{-}$ breast cancer groups. (3) $\beta 2-\mathrm{M}$ protein expression has a negative correlation with ER protein expression, a positive correlation with $\mathrm{p} 53$ protein expression and no correlation with Ki67 protein expression. (4) $\beta 2-\mathrm{M}$ siRNAs have different silencing effects in the different breast cancer molecular subtypes; it significantly inhibited Bcl-2 mRNA expression and did not inhibit the ER, PR and HER-2 mRNA expression in MCF-7 cells (ER ${ }^{+}, \mathrm{PR}^{+}$and HER-2 ${ }^{-}$); however, there was significant up-regulation in the $\mathrm{Bcl}-2$ and HER-2 mRNA expression levels in MDA-MB-231 cells $\left(\mathrm{ER}^{-}, \mathrm{PR}^{-}\right.$and HER-2- ${ }^{-}$, which is also consistent with the silencing effect at the protein level.

In conclusion, the aforementioned results demonstrate the following. First, the expression levels of the $\beta 2-\mathrm{M}$ transcript show no significant difference between different breast cancer molecular subtypes, and no significant association with age, clinical stage or lymph node metastasis. Second, the expression level of the $\beta 2-\mathrm{M}$ protein was significantly up-regulated by upstream genes or factors in breast cancer; its expression has different regulation pathways in the different breast cancer molecular subtypes, and has a negative correlation with ER protein

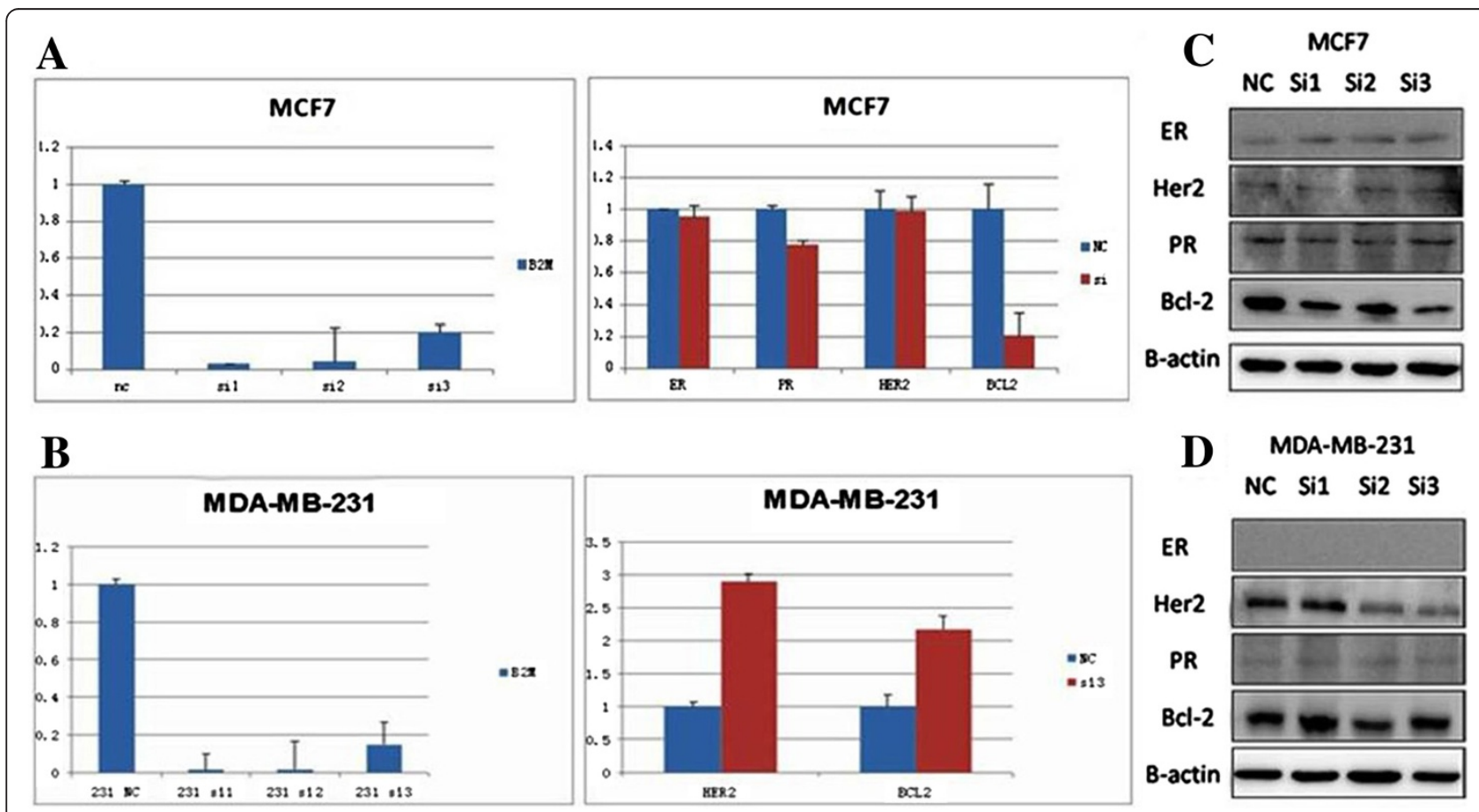

Figure 2 Silencing of the $\beta 2-M$ gene by siRNAs in breast cancer cells. A) $\beta 2-M$ siRNAs significantly inhibited the Bcl-2 mRNA expression, but did not inhibit the ER, PR, and HER-2 mRNA expression in MCF-7 cells (ER ${ }^{+}, \mathrm{PR}^{+}$and HER-2-); B) $\beta 2-\mathrm{M}$ siRNAs significantly up-regulated the Bcl-2 and HER-2 mRNA expression in MDA-MB-231 cells (ER ${ }^{-}, \mathrm{PR}^{-}$and HER-2-); C) ER, HER-2, PR and BCl-2 protein levels in MCF-7 cells, with or without $\beta 2-M$ siRNAs; D) ER, HER-2, PR and BCl-2 protein levels in MDA-MB-231 cells, with or without $\beta 2-M$ siRNAs. 
expression. Therefore, the expression of the $\beta 2-\mathrm{M}$ protein may be regulated by other signaling pathways beside the ER signaling pathway; the mechanism of this regulation needs to be further defined. Third, $\beta 2-\mathrm{M}$ transcript expression has a positive correlation with $\mathrm{Bcl}-2$ transcript expression. Consequently, the overexpression of $\beta 2-\mathrm{M}$ transcripts may cause up-regulation of the Bcl-2 transcripts in breast cancer, and restrain apoptosis in breast cancer cells. Bcl-2 is a target protein of the ER genome singling pathway in breast cancer cells (MCF-7), and modulates apoptosis in breast cancer cells [16]. ER $\alpha$ is a key molecule of ER singling pathway $[17,18]$, and estrogen can markedly promote the proliferation of breast cancer cells with ER $\alpha$ overexpression [19]. Therefore, $\beta 2-\mathrm{M}$ may promote proliferation and restrain apoptosis in breast cancer cells through the ER genome singling pathway in breast cancer with ER overexpression. Fourth, $\beta 2-\mathrm{M}$ siRNAs significantly inhibited Bcl-2 mRNA expression, but did not inhibit ER, PR and HER-2 mRNA expression in breast cancer cells with $\mathrm{ER}^{+}, \mathrm{PR}^{+}$and HER-2 ${ }^{-}$status. In contrast, there was significant up-regulation in Bcl-2 and HER-2 mRNA expression levels in breast cancer cells with $\mathrm{ER}^{-}$, $\mathrm{PR}^{-}$and HER-2 ${ }^{-}$status. The different breast cancer molecular subtypes are caused by different pathologies [20], are regulated by different singling pathways, and $\beta 2-\mathrm{M}$ may have different functions in the different breast cancer molecular subtypes. Other studies have shown that $\beta 2-\mathrm{M}$ is a signaling and growth-promoting factor for human renal cell carcinoma and prostate cancer bone metastasis. Interrupting the $\beta 2-\mathrm{M}$ signaling pathway may induce apoptosis in tumor cells and $\beta 2-\mathrm{M}$ may stimulate growth and improve osteocalcin (OC) and bone sialoprotein (BSP) gene expression in human prostate cancer cells via activating cyclic AMP (cAMP)-dependent PAK signaling pathway $[10,21]$. Human $\beta 2-\mathrm{M}$ monoclonal antibodies may have the effect of inducing apoptosis in vitro, and have therapeutic effects in mouse models of myeloma and other hematological tumor cells. The monoclonal antibodies may induce apoptosis and accomplish therapeutic functions by activating the c-Jun N-terminal kinase (JNK) and the caspase-9-dependent cascade, inhibiting PI3K (Phosphatidylinositol-3 kinase)/Akt and ERK (extracellular signal-regulated kinase) [13]. $\beta 2-\mathrm{M}$ may accelerate human renal cell carcinoma cell growth via activation of PI3K/Akt and ERK, and induce phosphorylation of the $\mathrm{Bcl}-\mathrm{xL} / \mathrm{Bcl}$-2-associated death promoter (Bad). The $\beta 2-\mathrm{M}$ antibody may induce the human renal cell carcinoma cells apoptosis by inhibiting the phosphorylation of Akt and ERK, and activating JNK, resulting in the phosphorylation of $\mathrm{Bcl}-2$ and decreased phosphorylation of Bad, leading to apoptosis [22]. Thereby, we deduced that $\beta 2-\mathrm{M}$ may resist apoptosis by activating PI3K/Akt and ERK. Moreover, the $\beta 2-\mathrm{M}$ siRNAs inhibited Bcl-2 mRNA expression by inhibiting the phosphorylation of Akt and ERK in breast cancer cells with ER overexpression. HER-2 may increase the antiapoptotic proteins survivin and Bcl-2 via activating the ERK and PI3K signaling pathways [23]. Accordingly, $\beta 2-\mathrm{M}$ may promote apoptosis by inhibiting HER-2 expression, resulting in inhibition of PI3K/Akt and ERK signaling pathways. In addition, $\beta 2-\mathrm{M}$ siRNAs may up-regulate the Bcl-2 mRNA expression via increasing HER-2 expression in breast cancer cells with $\mathrm{ER}^{-}, \mathrm{PR}^{-}$and HER-2- status. However, the regulation of the $\beta 2-\mathrm{M}$ signaling pathways in the different breast cancer molecular subtypes need further study.

Briefly, the results of this study indicate that expression of $\beta 2-\mathrm{M}$ is significant differences in four breast cancer molecular subtypes, which may lead to different functions of apoptosis regulation in breast cancer. These results will also be useful to understanding $\beta 2-\mathrm{M}$ signaling pathways regulation, and help to identify new targets for the treatment of breast cancer patients.

\section{Conclusions}

The expression of $\beta 2-\mathrm{M}$ is significantly different in four breast cancer molecular subtypes, and the $\beta 2-\mathrm{M}$ siRNAs have different silencing effects in the different breast cancer molecular subtypes. $\beta 2-\mathrm{M}$ may be involved in apoptosis regulation of breast cancer, and understanding the regulation of the $\beta 2-\mathrm{M}$ signaling pathways will help to identify new targets for the treatment of patients with breast cancer.

\section{Abbreviations}

ß2-M: Beta-2-microglobulin; Bcl-2: B-Cell Lymphoma/Leukemia 2; ER: Estrogen receptor; PR: Progesterone receptor; HER-2: Human epidermal growth factor receptor 2; p53: Tumor protein 53; PAK: p21-activated kinases; VEGF: Vascular endothelial growth factor; FFPE: Formalin-fixed, paraffin-embedded; TNM: Tumor-node-metastasis; IHC: Immunohistochemical; PBS: Phosphatebuffered saline; DBA: 3-3'-Diaminobenzidine; T: Tumor tissue; N: Normal tissue; OC: Osteocalcin; BSP: Bone sialoprotein; CAMP: Cyclic AMP; JNK: c-Jun N-terminal kinase; PI3K: Phosphatidylinositol-3 kinase; ERK: Extracellular signal-regulated kinase; Bad: BCl-xL/BCl-2-associated death promoter.

\section{Competing interests}

The authors declare that they have no competing interests.

\section{Authors' contributions}

LKS and DHF were responsible for experimental design, interpretation of the results and writing the manuscript. LKS, DHF, XWL, DDC and CYW performed the experimental procedures. SSY, XZC and RY were responsible for providing samples. All authors read and approved the manuscript.

\section{Acknowledgements}

This work was supported by grants from Natural Science Foundation of China (81060247).

\section{Author details}

Department of Medicine Biotechnology, Medicine and Science Research Institute of Gansu Province, Lanzhou, China. '2Department of Breast Surgery, Tumor Hospital of Gansu Province, Lanzhou, China. ${ }^{3}$ Department of Surgery, Tumor Hospital of Gansu Province, Lanzhou, China. ${ }^{4}$ Department of Pathology, Tumor Hospital of Gansu Province, Lanzhou, China.

Received: 20 June 2014 Accepted: 2 October 2014

Published: 7 October 2014 


\section{References}

1. Gresswell P, Springer T, Strominger UL, Turner MJ, Grey HM, Kubo RT: Imunological identity of the small subunit of HL-A antigens and $\beta_{2}$-microglobulin and its turnover on the cell membrane. Proc Natl Acad Sci 1974, 71:2123-2127.

2. Grey HM, Kubo RT, Colon SM, Poulik MD, Gresswell P, Springer T, Turner MJ, Strominger JM: The small subunit of $\mathrm{HL}-\mathrm{A}$ antigens is $\beta 2$-microglobulin. J Exp Med 1973, 138:1608-1612

3. Karlsson FA, Groth T, Kege K, Wibell L, Peterson PA: Turover in humans of B2-microglobulin. Eur J Clin Invest 1980, 10:293-300.

4. Hansen PB, Olsen NV: Beta 2-microglobulin in medical disease. Ugeskr Laeger 1989, 151:2960-2962.

5. Wibell $L$ : The serum level and urinary excretion of $\beta 2$ microglobulin in health and renal disease. Pathol Biol 1978, 26:295-301.

6. Klein T, Levin I, Niska A, Koren R, Gal R, Schachter J, Kfir B, Narinski R, Warchaizer $S$, Klein B: Correlation between tumor and serum $\beta 2 \mathrm{~m}$ expression in patients with breast cancer. Eur J Immunogenet 1996, 23:417-423.

7. Tsimberidou AM, Kantarjian HM, Wen S, O'Brien S, Cortes J, Wierda WG, Koller C, Pierce S, Brandt M, Freireich EJ, Estey EH: The prognostic of serum $\beta_{2}$ microglobulin levels in acute myloid leukemia and prognostic scores predicting survival: analysis if 1180 patients. Clin Cancer Res 2008, 14:721-730.

8. Gross M, Top I, Laux I, Katz J, Curran J, Tindell C, Agus D: $\beta$-2-microglobulin is an androgen-regulated secreted protein elevated in serum of patients with advanced prostate cancer. Clin Cancer Res 2007, 13:1979-1986.

9. Li KS, Du HF, Lian XW, Yuan M, Liu QJ, Yang SS, Chen XZ, Yang R, Ye WH: Serum $\beta 2$-microglobulin levels in patients with various solid cancer. J Mol Biomark Diagn 2012, S:2. http://dx.doi.org/10.4172/2155-9929.S2-007.

10. Huang WC, Wu D, Xie Z, Zhao HE, Nomura T, Zayzatoon M, Pohl J, Hsieh CL, Weitzmann MN, Farach-Carson MC, Chung LWK: $\beta 2$-microglobulin is a signaling and growth-promoting factor for human prostate cancer bone metastasis. Cancer Res 2006, 66:9108-9116.

11. Huang WC, Havel JJ, Zhau HE, Qian WP, Lue HW, Chu CY, Nomura T, Chung LWK: $\beta 2$-microglobulin signaling blockade inhibited androgen receptor axis and caused apoptosis in human prostate cancer cells. Clin Cancer Res 2008, 14:5341-5347.

12. Huang WC, Zhau HE, Chung LW: Androgen receptor survival signaling is blocked by anti- $\beta 2$-microblobulin monoclonal antibody via a mitogen-activated protein kinase/lipogenic pathway in human prostate cancer cells. J Biol Chem 2010, 285:7947-7985.

13. Yang J, Qian J, Wezeman M, Wang S, Lin P, Wang M, Yaccoby S, Kwak LW, Barlogie B, Yi Q: Targeting $\beta_{2}$-microglobulin for induction of tumor apoptosis in human hematological malignancies. Cancer Cell 2006 10:295-307.

14. Perou CM, Sorlie T, Eisen MB, van de Rijn M, Jeffrey SS, Rees CA, Pollack J, Ross DT, Johnsen H, Aksien LA, Fluge O, Pergamenschikov A, Williams C, Zhu SX, Lonning PE, Borresen-Dale AL, Brown PO, Botstein D: Molecular portraits of human breast tumours. Nature 2000, 406:747-752.

15. Josson S, Nornura T, Lin JT, Huang WC, Wu D, Zhau HE, Zayzafoon M, Weizmann MN, Gururajan M, Chung LW: $\beta 2$-Microglobulin induces epithelial to mesenchymal transition and confers cancer lethality and bone metastasis in human cancer cells. Cancer Res 2011, 71:2600-2610

16. Elumatai $P$, Gunadharini DN, Senthilkunar K, Banudevi $S$, Arunkumar $R$, Benson CS, Sharmila G, Arunakaran J: Induction of apoptosis in human breast cancer cells by nimbolide through extrinsic and intrinsic pathway. Toxicol Lett 2012, 215:131-142.

17. Barone I, Brusco L, Fuqua SA: Estrogen receptor mutations and changes in downstream gene expression and signaling. Clin Cancer Res 2010, $16: 2702-2708$

18. Yamaguchi Y: Microenvironmental regulation of estrogen signals in breast cancer. Breast Cancer 2007, 14:175-181.

19. Dhar K, Banerjee S, Dhar G, Senqupta K, Banerjee SK: Insulin-like growth factor-1 (IGF-1) induces WISP-2/CCN5 via multiple molecular cross-talks and is essential for mitogenic switch by IGF-1 axis in estrogen receptor-positive breast tumor cells. Cancer Res 2007, 67:1520-1526.

20. Tamimi RM, Colditz GA, Hazra A, Baer HJ, Hankinson SE, Rosner B, Marotti J, Connolly JL, Schnitt SJ, Collins LC: Traditional breast cancer risk factors in relation to molecular subtypes of breast cancer. Breast Cancer Res Treat 2012, 131:159-167.
21. Nomura T, Huang WC, Zhau HE, Wu D, Xie Z, Mimata H, Zayzafoon M, Young AN, Marshall FF, Weitzmann MN, Chung LW: $\beta_{2}$-microglobulin promotes the growth of human renal cell carcinoma through the activation of the protein kinase A, cyclic AMP-responsive element-binding protein, and vascular endothelial growth factor axis. Clin Cancer Res 2006, 12:7294-7305.

22. Nomura T, Huang WC, Seo S, Zhau HE, Mimata H, Chung LW: Targeting ß2-microglobulin mediated signaling as a novel therapeutic approach or human renal cell carcinoma. J Urol 2007, 178:292-300.

23. Siddiqa A, Long LM, Li L, Marciniak RA, Kazhdan I: Expression of HER-2 in MCF-7 breast cancer cells modulates anti-apoptotic proteins survivin and $\mathrm{BCl}-2$ via the extracellular signal-related kinase (ERK) and phosphoinositide-3 kinase (PI3K) signalling pathways. BMC Cancer 2008, 8:129.

doi:10.1186/1471-2407-14-750

Cite this article as: Li et al:: Characterization of $\beta 2$-microglobulin expression in different types of breast cancer. BMC Cancer 2014 14:750.

\section{Submit your next manuscript to BioMed Central and take full advantage of:}

- Convenient online submission

- Thorough peer review

- No space constraints or color figure charges

- Immediate publication on acceptance

- Inclusion in PubMed, CAS, Scopus and Google Scholar

- Research which is freely available for redistribution
Ciomed Central 